\title{
Locally Advanced Unresectable Breast Carcinoma
}

National Cancer Institute

\section{Source}

National Cancer Institute. Locally Advanced Unresectable Breast Carcinoma. NCI

Thesaurus. Code C162182.

A breast carcinoma that has spread from its original site of growth to nearby tissues or lymph nodes and is not amenable to surgical resection. 